\title{
Biotechnology: a case of delayed international convergence?
}

\section{Jorge Niosi}

Department of Management and Technology,

Canada Research Chair on the Management of Technology,

Université du Québec à Montréal (UQAM),

P.O. Box 8888 Station Centre-Ville,

Montreal H3C 3P8, Canada

E-mail: niosi.jorge@uqam.ca

\begin{abstract}
Catching up and leapfrogging regularly occur in capitalist economies, both at the level of entire countries and specific industries. The USA has taken the lead in biopharmaceuticals and has kept it for over fifty years. Biotechnology is now helping the US pharmaceutical industry to keep its global leadership patent and product figures or biotechnology drugs indicate that the USA is keeping its lead, and is not going to be left behind by any other nation, advanced or emerging, in the foreseeable future.
\end{abstract}

Keywords: biotechnology drugs; catching up; public biotechnology policy; emerging countries in biotechnology; USA leadership in biotechnology; biotechnology drug approval.

Reference to this paper should be made as follows: Niosi, J. (2014) 'Biotechnology: a case of delayed international convergence?', Int. J. Biotechnology, Vol. 13, Nos. 1/2/3, pp.5-21.

Biographical notes: Jorge Niosi is a Professor at UQAM since 1970 and Canada Research Chair on the Management of Technology since 2001. He is the author, co-author, editor or co-editor of 15 books, the latest being Building National and Regional Innovation Systems (Cheltenham, Elgar, 2010). He has published over 50 articles in refereed journals including Cambridge Journal of Economics, Industrial and Corporate Change, Journal of Business Research, Journal of Development Studies, Journal of Evolutionary Economics, Journal of Technology Transfer, International Journal of Biotechnology, Management International Review, Research Policy, R\&D Management, Revue d'économie industrielle, Small Business Economics, Technovation and World Development. His work is widely cited. He is a Fellow of the Royal Society of Canada (Academy N. 2) since 1994. He has consulted for the Inter-American Development Bank, UNIDO, CIDA, IDRC, Industry Canada, Statistics Canada and other national and international agencies. 


\section{Introduction}

Biotechnology is a set of technologies applied in many different industries across the globe. Today, such countries as the Canada, Germany, and UK but also Argentina, Brazil, China, India and Israel are incorporating biotechnology in agriculture, energy products and pharmaceuticals. Biotechnologies were born in the UK and the USA in the last 50 years but the latter has taken the lead both in the science and in the commercial application of biotechnologies. We have shown elsewhere that the rest of the world is slowly catching up in the science of biotechnology (Niosi et al., 2010), and that patent figures indicate that the USA is keeping the global lead in its commercial applications (Niosi, 2011). The goal of this paper is to bring new evidence from the biopharmaceutical industry confirming what the patent record indicates: the diffusion of biotechnology beyond the borders of the USA is slow. The paper hypothesises that the reasons for such sluggish diffusion are the massive public support of the US Government to the industry via such institutions as the National Institutions of Health (NIH), the unique character of the US public research system, the large and protected US drug market and the concentration of venture capital in the same country. Most probably, these and other factors reinforce each other in a series of positive feedback loops that create barriers to catching up by other nations.

\section{Theory: convergence, divergence and catching up}

In neoclassical economic theory, countries tend to convergence in productivity, through the fast adoption by laggard countries of institutions and technologies developed in more advanced nations. Also, the returns to capital investment would be higher in counties where capital is scarce, thus a tendency for capital investment to grow faster in backward nations. Thus catching up would occur across the international economy. Technology would flow to less developed countries through capital stock, and human capital would be produced by mimicking the institutions of more advanced countries.

In the 1960s, the product life cycle (PLC) approach (Vernon, 1966) made an effort to understand the micro-economic underpinnings of international trade and investment. According to the PLC approach, technological innovation appears first in rich countries, such as the USA, where potential markets are more affluent to test new products, and companies are more innovative because they possess more resources in order to innovate. The original innovators would initially export products to less developed countries, and later they would invest in those countries in an effort to impede the emergence of imitators. Yet imitators do emerge, and they would become able to copy the products originally produced in richer countries, as goods, services and processes standardise and markets become large, known and experienced. Through this process, capital and technology flows from more advanced to more backward regions and contribute to international economic convergence. Products from developing countries invade the markets of advanced countries. Such international trade patterns have been observed in many goods and services, from textiles to automobiles. Yet, Vernon and his school did not pay attention to the institutional conditions that allow some countries to attract international investment, launch new companies and reverse the original trade flows. They took for granted that the appropriate institutions would easily be imitated in developing countries. 


\subsection{Convergence and catching up}

From Maddison (1982) and Abramovitz (1986) on, economic historians have raised questions about the supposed international convergence in terms of total factor productivity. Both Abramovitz and Maddison found periods of convergence and periods of divergence, regional convergence in different parts of the world followed by periods where previous leaders fell behind and were replaced by other countries. Many other authors brought fresh evidence to demonstrate that convergence was neither universal nor fast (Maddison, 2007; Reinert, 2007).

Abramovitz hypothesised that 'social capabilities' were a major part of the explanation for delays in convergence. By 'social capabilities', he meant institutions in a large sense. North (1990) went further in the same direction: institutions are at the basis of economic development. Since the late 1980s, based on this paradigmatic shift, the innovation systems approach insisted on the role of institutions, but pinpointed only those related to science, technology and innovation as a source of growth or retardation (Lundvall, 1992; Nelson, 1993). They thus gave a more precise definition of those social capabilities. What mattered more for catching up and convergence were the quantity and quality of higher education institutions, public research laboratories, as well as science, technology and innovation policies. But such institutions were not easy to replicate for many reasons including organisational inertia, path dependence, cost and cultural factors (Niosi, 2002, 2010, 2011). For catching up countries to converge, they would need to build up such institutions through decades of patient investment; the difficulties involved in such long process of institution building are immense. The benefits of adopting such institutions are not evident, due to causal ambiguity, and barriers related to local vested interest in developing are also formidable.

Later on, institutional and evolutionary approaches, among others, have shown that overall productivity and convergence was better understood if it was decomposed sector by sector. Most countries have a small population, and are thus made of a small set of sectors ${ }^{1}$, and these are industries with specific technologies and idiosyncratic institutional supports. In other words, catching up is industry specific. The macro-economic approach to convergence hides major industrial gaps within the same country. Thus, if the catching up hypothesis argues that backwardness entails a potential for higher productivity growth rates, it is possible for a country to catch up in one industry and lag behind in others. South Korea has caught up in several segments of the information technology industries, but lags behind in aerospace and pharmaceuticals. Yet, due to the relative size of these two sets of industries, overall productivity in South Korea is high and the country's productivity keeps moving closer to North America and Western Europe.

Accordingly, because sectors have different institutional frameworks, catching up countries may have adopted institutional best practices in some industries and not in others.

\subsection{Leapfrogging}

Leapfrogging has been several times argued in the economic literature as a process through which developing countries adopt a new technology that is overlooked by leading countries, and combined to lower wages, allows them to rapidly increase their productivity and leave behind previous economic leaders (Brezis et al., 1993). Using Maddison's calculations, Brezis et al. (1993) show that by the 1950s, the USA had 
leapfrogged the UK and the Netherlands (in terms of GDP per capita), and that by 1979, Japan had also bypassed these two previous world leaders.

Other authors suggest that two stable situations can be observed in international trade: either 'persistent leadership' in which a country acquires an advantage at the origins of an industry and the advantage increases over time though endogenous growth positive feedback mechanisms, or 'catching up and leapfrogging'. In the this second situation, the leading nation may be less eager to change and adopt the new technology, or it has major sunk costs in a particular technology, and would suffer major losses if it tries to adopt the new technology (Motta et al., 1997). A case in point is railway technology. The USA has basically abandoned this set of technologies in favour of road transportation and has been leapfrogged by continental European countries and Japan with their high-speed trains. In turn, China is the only country that has adopted the magnetic levitation railway technology invented in Germany, and seems poised to leapfrog the USA, Japan and the European Union in this industry.

These papers have treated leapfrogging as a macro-economic process, and they measure it through aggregate productivity figures. Other authors have focused their work on new technologies. Perez and Soete (1988) suggested that new technologies sometimes offered windows of opportunity for backward countries to catch up. Indeed, they argued that developing countries should pay more attention to such types of opportunity than to older technologies, that offered easier and faster productivity growth, but also present the risk of getting stuck in technological impasses, competing only on the basis of low salaries. It is clear that this latter scenario is one that one can observe in many developing countries.

When examining South Korean catching up processes in several industries, Lee and Lim (2001) suggest that there are at least two different types of leapfrogging, and both are different from path-following catching up. Path-skipping leapfrogging is one where the backward country jumps over one or several phases in the development of the industry. Present-day China adopting the latest generation of maglev trains is a case in point. Path-creating catching up is a second type of leapfrogging, in which the developing country creates its own path to development.

\subsection{Catching up in traditional industries}

In traditional industries, catching up is generally well described by the product life cycle and industry life cycle models. In these industries, technology is born in advanced and affluent countries, it tends to standardise as markets are known, economies of scale emerge, and companies compete through delocalising operations to low cost countries. This has happened in most low-technology industries such as food and beverages, apparel, leather products, furniture and many metal products. In time, third world multinationals (Wells, 1983) to produce simpler copies of the same products for less affluent markets.

In medium technology markets the process of catching up is not extremely different. In automobiles, machinery, naval construction, metal processing and petrochemicals one finds such processes of delocalisation, and eventual emergence of developing country multinational companies.

Lee and Lim (2001) and Kim (1997) have seen several possible scenarios within these traditional path-following catching-up processes. At one extreme, developing country companies emerge and begin a process of technology accumulation and 
innovation. This has happened in South Korea in automobiles and naval construction. Kim (1997) calls these processes 'acquisition', 'assimilation' and 'improvement'. At the other extreme, the diffusion of technology in the developing countries remains in the hands of foreign multinational corporations. This is the case in Mexico's maquiladora industries such as the automobile, the electronics and more recently in aerospace, and pharmaceuticals. It is also visible in Brazilian car industries. Such a path following catching-up process is less conducive to continuous productivity growth, according to Lee and Lim (2001).

\subsection{Catching up in high-tech industries}

Perez and Soete (1988) tried to focus on catching up in new, high-tech industries. In the past, high-technology migration to developing countries has proved more elusive.

In the last forty years, few countries have been able to catch up, and less still have been able to leapfrog in high tech industries. Japan, Canada, Finland, Singapore, South Korea and Taiwan come immediately to our minds (Niosi, 2010). In the post-war period, the catching up of Japan in a vast array of high-tech industries elicited a large number of books and articles, as well as a large debate about the role of the state in the catching-up process. Was it industrial policy or the neutrality of the state that nurtured the Japanese miracle? (Johnson, 1982; Okimoto et al., 1984; Okimoto, 1989; World Bank, 1993).

Canada's catching up has been evident in the aerospace industry, while Finnish and South Korean catching up was strong in information technology. Singapore is exporting over 100 billion dollars per year in electronic technology, pharmaceutical products, and aerospace equipment. These countries pursued different organisational paths. Finland, South Korea and Taiwan organised their catching up around national firms, while Singapore caught up through inward foreign direct investment of multinational corporations (Archibugi and Pietrobelli, 2003; Goh, 2006). Canada adopted a mixed strategy of industrialisation by invitation, and parallel support to national firms.

In all cases, government support for high-technology development has been pervasive, including the creation of public research laboratories, advanced university degrees, and new or revamped innovation policies.

\subsection{Catching up in biopharmaceuticals}

Catching up has been more elusive in biopharmaceuticals. A few emerging countries, including Argentina, Brazil, China, South Korea and India have nurtured a generic pharmaceutical industry over several decades with a combination of some degree of protectionism, a drug patent system that allowed patents for processes but not for products, and a fairly large internal or regional market. Since the 2000, however, they have signed the TRIPS agreement and their patent legislation has allowed protection for drugs. Since then, large multinational corporations have acquired some of their largest domestic pharmaceutical companies. Yet, the remaining ones are making efforts to produce biosimilar drugs, or drugs that have lost their patent protection such as biosynthetic insulin, several types of interferon, human growth hormones, colony stimulating factors (CSF), erythropoietin $\left(\mathrm{EPO}^{2}\right)$ and others, and have been able to export 
them to other developing countries. This path-following catching up process has not been easy. Several obstacles have been erected to their technology acquisition.

For one, the FDA, applying US Congress Biologics and Price Competition Act (2009) requires that biosimilar drugs, to be approved, must be as safe as effective as the original drug. The Act was implemented on the basis that these large molecules may not be either identical or as stable as the ones produced in the USA. For several years, emerging countries producing biosimilar drugs may be thus barren from the US market, the largest and most affluent in the world. Similar trade obstacles exist in Japan and the European Union. However, the European Union may be less restrictive than the USA, as most intellectual property on biotechnology drugs belongs to US companies.

For two, in 2009, the US Congress has also added a 12-year exclusivity of research data concerning biotechnology processes leading to biotechnology-based drugs. In this way, imported products will not be identical to US ones, and US firms can prolong their leadership well after the product patent has expired.

Emerging countries may thus develop their biosimilar products and sell them in unregulated, but less affluent markets in developing countries. Thus Indian companies are already selling biosimilars in three continents (Africa, Asia and Latin America) while Latin American companies are mostly confined to the South American markets.

\section{The continuous US leadership in biotechnology}

The importance of the biopharmaceutical industry has been a subject of some dispute. One can find authors that argue - with data - that biological drugs have increased longevity, reduced hospitalisation and on the whole that OECD countries have had a major return for their investments in biopharmaceutical R\&D (Lichtenberg, 1998, 2001, 2005, 2008; Cockburn and Stern, 2010). In 2011 the Biotechnology Industry Organization has released data showing that large molecule drugs are twice as successful in gaining approval than small molecule drugs. In 2012, a full $30 \%$ of the FDA approvals were biologics, but peptides and enzymes rather than MABs. In the meantime gene therapy clinical trials are moving forward, and new disciples (pharmacogenomics and proteomics being among the most noticeable) are making their appearance thank to the fast development of genomics and bioinformatics. The genes associated with thousands of diseases are being identified. In these new fields, US leadership is staggering. Such US firms as 454, Affymetrix, Agilent, Applied Biosystems, GE, Life Technologies, and Illumina, produce the vast majority of hardware equipment used in these new disciplines.

Other authors have a more sceptical view (Hopkins et al., 2007). The fact is that life sciences have been growing in all OECD countries, at such a pace that the term innovation cascade that was used for other disciplines can be used in biotechnology.

Since the beginnings of the molecular biology revolution in pharmaceuticals in the early 1980s, the USA has become and remains the undisputed leader in biotechnology, both in its science and its commercial applications. We have showed elsewhere that the share of biotechnology patents in the USA has increased in the world total (Niosi, 2011 and Table 1). In terms of patents, the rest of the world is not catching up. Yet, the giant investments of some new countries such as China may allow her to catch up and even leapfrog is areas such as gene therapy or genomics. 
Biotechnology: a case of delayed international convergence?

Table 1 US biotechnology patents 1985-2006 main region and country

\begin{tabular}{lcccc}
\hline Country/region & $\begin{array}{c}\text { Number of } \\
\text { patents } 1985-95\end{array}$ & $\begin{array}{c}\text { \% world patents } \\
\text { 1985-95 }\end{array}$ & $\begin{array}{c}\text { Number of } \\
\text { patents } 1996-2006\end{array}$ & $\begin{array}{c}\text { \% world patents } \\
\text { 1996-2006 }\end{array}$ \\
\hline USA & 8868 & 60.8 & 37625 & 65.95 \\
EU & 2056 & 17.2 & 9965 & 17.46 \\
Japan & 2290 & 15.70 & 4416 & 7.7 \\
Germany & 840 & 5.76 & 2525 & 4.42 \\
Canada & 680 & 4.66 & 1928 & 4.22 \\
UK & 491 & 3.37 & 2044 & 3.58 \\
France & 365 & 2.5 & 1712 & 3 \\
Netherlands & 163 & 1.12 & 747 & 1.31 \\
Denmark & 101 & 0.69 & 745 & 1.31 \\
Belgium & 82 & 0.56 & 525 & 0.92 \\
Sweden & 134 & 0.92 & 517 & 0.91 \\
Italy & 134 & 2.6 & 379 & 0.61 \\
Austria & 52 & 0.36 & 252 & 0.44 \\
Finland & 68 & 0.47 & 213 & 0.37 \\
Spain & 27 & 0.34 & 121 & 0.21 \\
Singapore & 1 & 0.01 & 62 & 0.1 \\
South Korea & 31 & 0.21 & 408 & 0.72 \\
World & 14,586 & 100 & 57,044 & 100 \\
\hline
\end{tabular}

Source: NSF (2008)

Prevezer (2001) summarised some of the reasons for such permanent leadership as follows:

1 there are substantially more academic research funds in the USA than in Europe

2 easier for US academics to found start ups while retaining their academic posts

3 US start-ups are concentrated in human health and agricultural biotechnology, where commercial potential is higher

4 financing and managerial conditions are easier in the USA in terms of venture capital, stock market admissibility and access to managerial expertise

5 greater access of US dedicated biotechnology firms to alliances with large domestic and foreign pharmaceutical corporations.

Cockburn and Stern (2010) add other reasons for such leadership. First, life sciences are the largest sector of academic and public research in the USA. Second, there is a massive and stable public support for public research. Third, the USA is also the largest market for drugs and one that is able and willing to pay high prices for specialised drugs, such as monoclonal antibodies treating cancer, macular degeneration or multiple sclerosis, and fusion proteins for psoriasis or rheumatoid arthritis. Fourth, the regulatory system in the USA certifies a high level of reliability for the approved drugs, and also serves as a barrier against competition from low-cost generic and biosimilar producers based in 
emerging countries. Fifth, the intellectual property system insures both patent protection, and delayed divulgation of process technology for biopharmaceutical products. Sixth, there is strong competition at the academic level among scientific teams, among start-up companies and large domestic and foreign pharmaceutical corporations. Last but not least, the US Government has, since the 1950s, shown a high level of 'technological optimism' that led to the creation in 1950 of the National Science Foundation, with an annual budget in 2010 close to 7 billion USD, the National Institutes of Health (founded in 1930 and enlarged after WWII, with a 2010 budget of 31 billion USD). Also, the Food and Drug Administration (FDA) is a major component of the life sciences innovation system, growing from a small office in 1906 to an agency with a 3.2 billion USD budget and with 11,000 employees in 2010. The FDA approves new drugs and new indications for existing drugs after a long analysis of R\&D clinical assays; and it inspects pharmaceutical facilities to insure good manufacturing practices both in the USA and abroad for foreign companies willing to export drugs to the USA.

van Pottelsberghe (2007), former director of the European Patent Office, has added another factor: it is much easier and less costly to patent in the USA than it is in Europe. Biotechnology is a set of technologies that is most often protected by patents. An inefficient European Patent Office handicaps European dedicated biotechnology firms.

Aghion et al. (2007, 2009) as well as other authors highlighted the rigidities of the European university system plagued by high levels of in-breeding, low salaries, 27 national languages and dozens of regional ones, and the fact that in most EU countries university positions are reserved to European nationals. Some of these hurdles also affect many African, Chinese, Indian and Latin American higher education institutions.

Finally, the EU is composed of 25 national markets, fairly divided through institutional barriers of different kinds, against a unified US market.

It is thus understandable that the USA continues to dominate the commercial biotechnology landscape. In its major application industry, biopharmaceuticals, the USA keeps its huge lead against European biotechnology (Table 2).

Table 2 New FDA approved biological drugs by country of control of inventing firm, 1980-2010

\begin{tabular}{lcccc}
\hline Country & $1980-89$ & $1990-99$ & $2000-10$ & Total \\
\hline USA & $7(88 \%)$ & $28(74 \%)$ & $57(76 \%)$ & $92(76 \%)$ \\
Switzerland & 1 & 3 & 8 & $12(10 \%)$ \\
UK & 0 & 0 & 7 & 7 \\
Denmark & 0 & 4 & 0 & 4 \\
Germany & 0 & 2 & 1 & 3 \\
Sweden & 0 & 1 & 0 & 1 \\
France & 0 & 0 & 1 & 1 \\
Total Europe & $1(12 \%)$ & $10(26 \%)$ & $17(24 \%)$ & $28(24 \%)$ \\
World total & 8 & $38(100 \%)$ & $74(100 \%)$ & $120(100 \%)$ \\
\hline
\end{tabular}

Note: NB: excludes new applications for already approved drugs; excludes small molecules applied for by dedicated biotechnology firms.

Source: US FDA 
The specifics of the adoption of human health biotechnology by pharmaceutical companies in the USA, Western Europe and Japan have also been debated. Henderson et al. (1999) have suggested that European and Japanese pharmaceutical corporations have been slow in adopting the new biotechnology. Besides they argue that both Japan and Western Europe have not grown productive dedicated biotechnology firms as the USA did. Tijssen (2009) adds that European pharmaceutical firms have managed to recover some of their backwardness and strengthened their science base by acquiring US biotechnology firms. The acquisition of Genentech by Swiss Roche, Chiron by Swiss Novartis, and British AstraZeneca acquisition of MedImmune are some of the multibillion mergers that have no equivalent in the other way (US companies acquiring European ones).

Our figures bring some evidence in favour of part of their picture and tend to reject some other elements. Table 2 confirms that Japanese pharmaceutical corporations are notoriously absent from biotechnology innovation. The picture is somewhat different for Europe. In fact, several large Swiss pharmaceutical and biotechnology corporations have been very successful in getting NBE since the 1980s, including Hoffmann-Laroche, Serono, Helsinn, and Novartis. Large British pharmaceutical corporations such as Glaxo and Shire arrived later, after the 1990s. Denmark has Novo Nordisk as its major R\&D performer in biopharmaceuticals. In Germany, Bayer and Boehringer Ingelheim had new biological entities approved. Only two dedicated European Union biotechnology firms had NBE approved: UK Cambridge Antibody Technology and France's Ipsen with one product each, both approved after 2000.

In the USA, the vast majority of approved NBE were invented and submitted to the FDA by large dedicated biotechnology firms such as Amgen, Biogen, Centocor, Chiron, Genentech, Genzyme and InterMune. European and Japanese pharmaceutical companies purchased several of these DBFs as shown in Table 3, thus adding to their biotechnology capabilities. However, US pharmaceutical companies are also acquiring formerly independent biotechnology companies to new add capabilities and products to their pipelines.

Table 3 Main US dedicated biotechnology firms acquired by European and Japanese companies

\begin{tabular}{lcccc}
\hline Acquired firm & Acquiring firm & $\begin{array}{c}\text { Nationality of } \\
\text { acquiring firm }\end{array}$ & $\begin{array}{c}\text { Year of } \\
\text { acquisition }\end{array}$ & $\begin{array}{c}\text { Cost of } \\
\text { acquisition } \\
\text { (current US\$) }\end{array}$ \\
\hline Genentech & Roche & Switzerland & $1990-99$ & 50 billion \\
Chiron & Novartis & Switzerland & $1996-2006$ & 5.1 billion \\
Genzyme & Sanofi-Aventis & France & 2011 & 20 billion \\
VaxDesign & Sanofi-Aventis & France & 2010 & 55 million \\
Millenium & Takeda & Japan & 2008 & 8.8 billion \\
OSI Pharmaceuticals & Astellas & Japan & 2010 & 4 billion \\
Medimmune & AstraZeneca & UK & 2007 & 15 billion \\
\hline
\end{tabular}

The reason is that their own pipelines of traditional small molecules is running dry, while the share of new biological entities in new drugs approved is rising as is shown in Figure 1 and Table 4. 
Figure 1 New drugs from small molecules versus biological entities (see online version for colours)

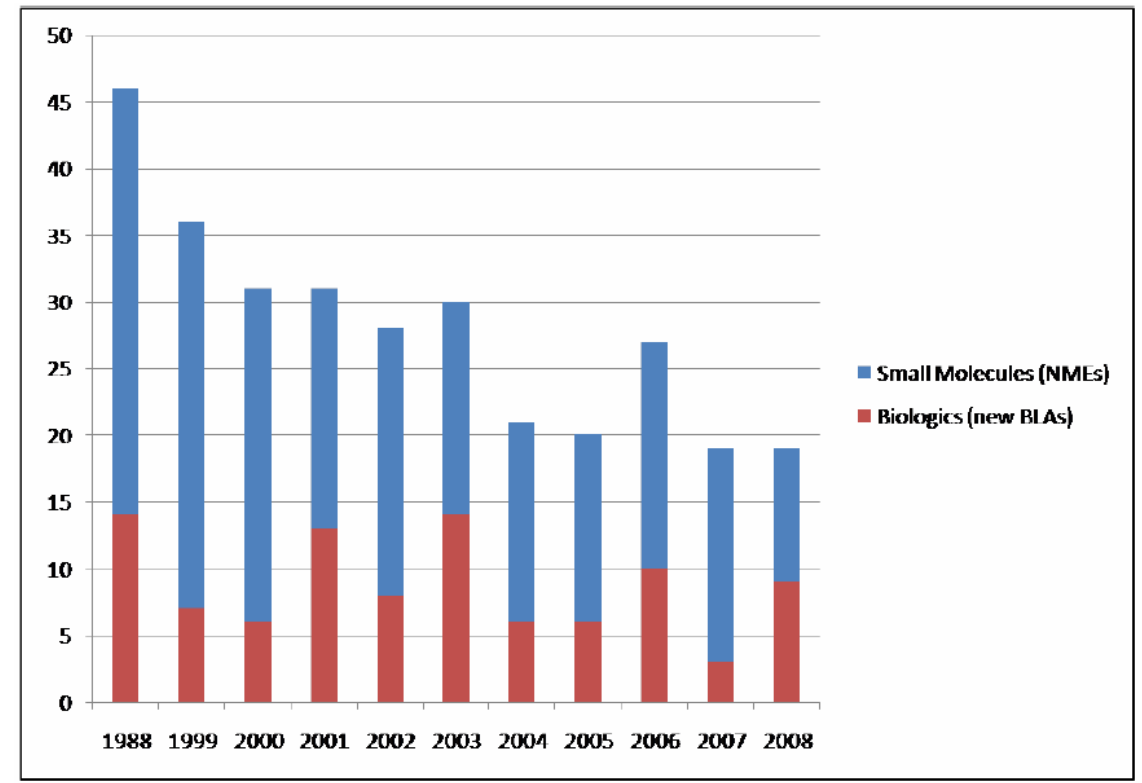

Table 4 New drugs from small molecules approved versus new biological drugs

\begin{tabular}{lccccccccccccc}
\hline & 1998 & 1999 & 2000 & 2001 & 2002 & 2003 & 2004 & 2005 & 2006 & 2007 & 2008 & 2009 & Total \\
\hline $\begin{array}{l}\text { Small } \\
\text { molecules }\end{array}$ & 32 & 29 & 25 & 18 & 20 & 16 & 15 & 14 & 17 & 16 & 10 & 11 & 223 \\
Biologics & 14 & 7 & 6 & 13 & 8 & 14 & 6 & 6 & 10 & 3 & 9 & 9 & 105 \\
Total & 46 & 36 & 31 & 31 & 28 & 30 & 21 & 20 & 27 & 19 & 19 & 20 & 328 \\
\hline
\end{tabular}

Source: FDA

\section{Is there evidence about leapfrogging?}

But may be emerging and OECD countries are not catching up but leapfrogging in terms of developing future new biotechnology products. In order to test this hypothesis, information was gathered on two biotechnology fields: monoclonal antibodies and stem cells.

Monoclonal antibodies (MABs) are coming of age. They are proteins produced by B-lymphocytes in the immune system in response to antigens (foreign proteins). Antibodies bind to the antigens so that they can be recognised and destroyed by phagocytes. Each B cell synthesises just one type of antibody. From 2001 to 2010 the FDA approved some $16 \mathrm{MABs}$, and by mid-2010 there were some 25 of such antibodies in the market (Mintz, 2010). But hundreds of them are under development. They are used for the treatment of viral diseases, for diagnostics of drugs, hormones or toxins, for detection of cancer cells, to treat immune disorders, reduce the risk of transplant rejection in patients, and for other uses. The first therapeutic MAB was introduced in the US 
market in 1986 (Table 5). But the full potential of MABs as medicines was realised after 2000. By 2008, the global market for MABs was $\$ 28$ billion and growing very fast. Another sign of the times, pharmaceutical companies are acquiring MAB developers, often at high prices.

Table 5 Monoclonal antibodies in the market up to 2010*

\begin{tabular}{|c|c|c|c|c|c|}
\hline Year & $\begin{array}{c}\text { Biological name } \\
\text { of product }\end{array}$ & $\begin{array}{l}\text { Proprietary } \\
\text { names }\end{array}$ & Manufacturer & Country & Indication \\
\hline 1986 & Muronomab-CD3 & Orthoclone & OrthoBiotech (J\&J) & USA & Immunotherapy \\
\hline 1994 & Abciximab & ReoPro & Centocor & USA & Cardiovascular diseases \\
\hline 1997 & Rituximab & Rituxan & IDEC & USA & Cancer \\
\hline 1997 & Daclizumab & Zenapax & Roche & Swiss & Immunological \\
\hline 1998 & Infliximab & Remicade & Centocor & USA & Immunological \\
\hline 1998 & Palivizumab & Synagis & $\begin{array}{l}\text { Medimmune, } \\
\text { AstraZeneca }\end{array}$ & USA/UK & Anti-infective \\
\hline 1998 & Trastuzumab & Herceptin & Genentech & USA & Breast Cancer \\
\hline 1998 & Basiliximab & Simulect & Novartis & Swiss & Immunological \\
\hline 2000 & Gentuzumab & Mylotarg & Wyeth & USA & Cancer \\
\hline 2001 & Alemtuzumab & Campath & Genzyme & USA & Cancer \\
\hline 2002 & Ibritumomab & Zevalin & IDEC & USA & $\begin{array}{l}\text { B-cell non-Hodgkin } \\
\text { lymphoma }\end{array}$ \\
\hline 2002 & Adalimumab & Humira & $\begin{array}{l}\text { Cambridge } \\
\text { Antibody/ } \\
\text { US BASF }\end{array}$ & UK/USA & Rheumatoid arthritis \\
\hline 2003 & $\begin{array}{l}\text { Tositumab } \\
\text { Iodine }\end{array}$ & Bexxar & Corixa & USA & Radioimmunotherapy \\
\hline 2004 & Natalizumab & Tysabri & Biogen IDEC & USA & Multiple sclerosis \\
\hline 2004 & Bevacizumab & Avastatin & Genentech & USA & $\begin{array}{l}\text { Metastatic carcinoma } \\
\text { of colon and rectum }\end{array}$ \\
\hline 2004 & Cetuximab & Erbitux & ImClone Systems & USA & Colorectal carcinoma \\
\hline 2006 & Panitumumab & Vectibix & Amgen & USA & $\begin{array}{c}\text { Metastatic colorectal } \\
\text { carcinoma }\end{array}$ \\
\hline 2006 & Ranimizumab & Lucentis & Genentech & USA & Macular degeneration \\
\hline 2007 & Eculizumab & Soliris & Alexion & USA & To reduce hemolysis \\
\hline 2009 & Canakinumab & Ilaris & Novartis & Swiss & Cryopyrin \\
\hline 2009 & Ustekinumab & Stelara & Centocor & USA & Psoriasis \\
\hline 2009 & Ofatumumab & Arzerra & GlaxoSmithKline & UK & $\begin{array}{c}\text { Chronic lymphocytic } \\
\text { leukaemia }\end{array}$ \\
\hline 2010 & Denusomab & Prolia & Amgen & USA & $\begin{array}{c}\text { Postmenopausal } \\
\text { osteoporosis }\end{array}$ \\
\hline 2010 & Tocilizumab & Actemra & Roche & Swiss & Rheumatoid arthritis \\
\hline
\end{tabular}

Note: *A Cuban developed drug, Nimotuzunab, already administered in several countries through commercial sales, has now completed Phase II clinical trials in the USA and Canada.

Source: FDA 
Out of 24 MABs in the market at the end of 2010, the vast majority was invented and marketed in USA. Switzerland and the UK are distant second and third. Also, if patents are an early indicator of products in the pipeline, the USA domination of the MAB pipeline seems unassailable. Neither other OECD countries nor emerging countries seem close to the US technological level. Japan and Germany follow the USA in terms of patents.

Table 6 Leapfrogging in MABs? US patents 1976-2011 of OECD countries' assignees

\begin{tabular}{lc}
\hline Inventor country & US patents in MABs \\
\hline USA: ten major states & 2240 \\
Japan & 455 \\
Germany & 208 \\
France & 142 \\
UK & 132 \\
Canada & 122 \\
Netherlands & 66 \\
Belgium & 51 \\
Australia & 49 \\
Sweden & 48 \\
Italy & 36 \\
Denmark & 34 \\
\hline
\end{tabular}

Source: USPTO

Table 7 Leapfrogging in MABs? Emerging country patents, 1976-2011

\begin{tabular}{lc}
\hline Inventor country & US patents in MABS \\
\hline Korea & 28 \\
Chinese Taipei & 14 \\
China & 13 \\
Brazil & 3 \\
Russia & 3 \\
India & 2 \\
Argentina & 1 \\
Singapore & 1 \\
South Africa & 1 \\
Total emerging countries & 66 \\
\hline
\end{tabular}

Source: USPTO

If MABs are today's frontier, stem cell is the next one. Stem cell therapy is based on the introduction of new cells to replace injured or defective ones. Except for bone marrow stem cell transplantation all other applications are still in its infancy, like MABs were in the 1980s and early 1990s. But most qualified observers have no doubt that in the foreseeable future stem cell treatment will be used for cancer, cardiovascular diseases diabetes, neurodegenerative disorders, Parkinson disease and many others. 
Once again, stem cell patents show a massive dominance of the future therapeutic pipeline by US companies. Like in the case of MABs, Japan seems to be a distant second, followed in this case by Canada. Even OECD countries have some difficulties in following the US advances in new fields, as shown by Tables 8 and 9.

Table 8 Stem cell patents in advanced OECD countries, January 1976-April 2011

\begin{tabular}{lc}
\hline Inventor country & Stem cell patents \\
\hline USA California & 123 \\
USA Maryland & 56 \\
USA Massachusetts & 40 \\
USA New York & 30 \\
USA Florida & 21 \\
USA Washington & 19 \\
Total USA & 318 \\
Japan & 42 \\
Canada & 35 \\
Australia & 17 \\
UK & 16 \\
Germany & 12 \\
Sweden & 12 \\
Italy & 9 \\
France & 8 \\
Netherlands & 8 \\
Belgium & 3 \\
Denmark & 2 \\
\hline
\end{tabular}

Source: USPTO

Table 9 Stem cell patents in emerging countries, January 1976-April 2011

\begin{tabular}{lc}
\hline Inventor country & Stem cell patents \\
\hline Korea & 5 \\
India & 3 \\
Russian Fed. & 2 \\
Chinese Taipei & 1 \\
China & 1 \\
Singapore & 1 \\
South Africa & 1 \\
Argentina & 0 \\
Brazil & 0 \\
Mexico & 0 \\
Total emerging & 14 \\
\hline
\end{tabular}




\section{Conclusions}

We are witnessing the merger of human health biotechnology and the pharmaceutical industry. An increasing proportion of new drugs come now from biotechnology R\&D. The USA remains the undisputed frontrunner in human health $R \& D$, irrespective of the nationality of the firms that control their industrial biotechnology laboratories. In the meantime, as more biological entities loose their patent protection, emerging country pharmaceutical companies are increasingly copying those products and producing biogenerics. These countries include Argentina, Brazil, China, India, and South Korea. Yet the imitators seem unable to launch entirely new products, as they do not appear among the inventors of FDA-approved biological drugs ${ }^{3}$. We have proposed elsewhere that due to the high costs of producing new medicines, only some of these large emerging countries will in the foreseeable future join the ranks of nations having invented brand new biological drugs (Niosi and Reid, 2007). For such purpose, they will be obliged to substantially raise their investment in drug discovery for long periods of time. China appears without any doubt as the country that may catch up in, at least some areas, in the next twenty years, due to its recent massive investment in health $R \& D$, huge market for drugs and human capital pool.

Our research tends not only to reject convergence theories - but also bring support to the innovation system approach. Emerging countries, but also other OECD advanced industrial countries, seem unable to emulate the institutional innovation framework that has allowed the USA to take and conserve the lead in the biopharmaceutical industry. Tiny Switzerland is the major exception to this strong trend, as several of its pharmaceutical companies have been able to develop new biological drugs and get them approved at the FDA.

This paper tends also to bring a major caveat to product life cycle theories. The type of industry that has developed in emerging countries is fairly different from the one that has flourished in industrial countries, the USA in the first place. Imitative generic pharmaceutical industries have been growing in the largest emerging countries; few new drugs have yet been produced these 50-years old industries. Also, protectionism in advanced countries has been able to maintain the original flow of drugs, from rich advanced countries to emerging ones, while slowing the pace of the opposite flow. Generic products from emerging countries, and particularly bio-similar drugs, have been kept at bay in the markets of North America and Western Europe. Some emerging countries (Argentina, Brazil, China, India, and South Korea) do export drugs but they sell them in other emerging and developing countries, not to those where the original discoveries and production were made.

Also, Perez and Soete (1988) theory of new technologies as windows of opportunity is rebuked here. The reason is institutional. New technologies require experienced academic research, public R\&D laboratories, and science, technology and innovation policies, including sophisticated public support for public and private research and development. The crafting of such institutions has taken decades in the USA. It will take also decades for emerging countries to understand them, imitate them and make them nurture advanced technologies.

The policy implications of our study are straight forward: only emerging countries with a large academic establishment, massive and stable funding for health research in companies, public R\&D laboratories and research universities will be able in the future to catch up with the USA in terms of new biotechnology drugs. The list of contenders for 
such a difficult challenge is small. Among advanced OECD countries, the UK, Germany and Japan seem to maintain their (second or third) places. Among emerging countries, only China and India appear in the foreseeable future, and tomorrow may be Brazil and Russia would be such candidates.

\section{References}

Abramovitz, M. (1986) 'Catching up, forging ahead and falling behind', The Journal of Economic History, Vol. 46, No. 2, pp.385-406.

Aghion, P., Dewatripont, M., Hoxby, C., Mas-Collell, A. and Sapir, A. (2007) Why Reform Europe's Universities, Bruegel Policy Brief, Issue 2007/4, Brussels.

Aghion, P., Dewatripont, M., Hoxby, C., Mas-Collell, A. and Sapir, A. (2009) The Governance and Performance of Research Universities, NBER WP 14851, Cambridge, MA.

Archibugi, D. and Pietrobelli, C. (2003) 'The globalisation of technology and its implications for developing countries: windows of opportunity or further burden', Technological Forecasting and Social Change, Vol. 70, No. 9, pp.861-883.

Brezis, E., Krugman, P.R. and Tsiddon, D. (1993) 'Leapfrogging in international competition: a theory of cycles in national leadership', The American Economic Review, Vol. 83, No. 5, pp.1211-1219.

Cockburn, I. and Stern, S. (2010) 'Finding the endless frontier: lessons from the life sciences innovation system for technology policy', Capitalism and Society, Vol. 5, No. 1, Article 1.

Goh, A.L. (2006) 'Evolution of industrial policy-making in support of innovation: the case of Singapore', International Journal of Innovation and Learning, Vol. 3, No. 1, pp.110-125.

Henderson, R., Orsenigo, L. and Pisano, G.P. (1999) 'The pharmaceutical industry and the revolution in molecular biology: interactions among scientific, institutional and organizational change', in Mowery, D.C. and Nelson, R.R. (Eds.): Sources of Industrial Leadership, Cambridge University Press, Cambridge.

Hopkins, M.M., Martin, P.A., Nightingale, P., Kraft, A. and Mahdi, S. (2007) 'The myth of the biotech revolution: an assessment of technological, clinical and organisational change', Research Policy, Vol. 36, No. 4, pp.566-589.

Johnson, C. (1982) MITI and the Japanese Miracle. The Growth of Industrial Policy, 1925-1975, Tokyo, Tuttle and Co., Tokyo.

Kim, L. (1997) Imitation to Innovation, Harvard Business School Press, Boston.

Lee, K. and Lim, C. (2001) 'Technological regimes, catch up and leapfrogging: findings from the Korean industries', Research Policy, Vol. 30, No. 3, pp.459-483.

Lichtenberg, F.R. (1998) Pharmaceutical Innovation, Mortality Reduction and Economic Growth, NBER WP 6569, Cambridge, MA.

Lichtenberg, F.R. (2001) The Effect of New Drugs on Mortality from Rare Diseases and HIV, NBER WP 8677, Cambridge, MA.

Lichtenberg, F.R. (2005) 'The impact of new drug launches on longevity: evidence from longitudinal, disease level data from 52 countries, 1982-2001', International Journal of Health Care Finance and Economics, Vol. 5, No. 1, pp.47-73.

Lichtenberg, F.R. (2008) Have Newer Cardiovascular New Drugs Reduced Hospitalization? Evidence from Longitudinal Country Level Data on 20 OECD Countries, 1995-2003, NBER WP 14008, Cambridge, MA.

Lundvall, B-A. (Ed.) (1992) National Systems of Innovation, Pinter, London.

Maddison, A. (1982) Phases of Capitalist Development, Oxford University Press, New York.

Maddison, A. (2007) Contours of the World Economy, 1-2030 AD, Oxford University Press, New York.

Mintz, C. (2010) 'Monoclonal antibodies: the next generation', Life Science Leader, April. 
Motta, M., Thisse, J-F. and Cabrales, A. (1997) 'On the persistence of leadership and leapfrogging in international trade', International Economic Review, Vol. 38, No. 4, pp.809-824.

Nelson, R.R. (Ed.) (1993) National Innovation Systems, A Comparative Analysis, Oxford University Press, NY.

North, D. (1990) Institutions, Institutional Change and Economic Performance, Cambridge University Press, Cambridge.

NSF (2008) Science and Engineering Indicators, Vol. 2, National Academic Press, Washington DC.

Niosi, J. (2002) 'National systems of innovation are x-efficient (and x-effective) why some are slow learners', Research Policy, Vol. 31, No. 2, pp.291-302.

Niosi, J. (2010) Building National and Regional Innovation Systems, Institutions for Economic Development, Cheltenham, Elgar.

Niosi, J. (2011) 'Complexity and path dependence in biotechnology innovation systems', Industrial and Corporate Change, Vol. 20, No. 6, pp.1795-1826.

Niosi, J. and Reid, S. (2007) 'Biotechnology and nanotechnology: science-based technologies as windows of opportunity for LDCs?', World Development, Vol. 35, No. 3, pp.426-438.

Niosi, J., Hanel, P. and Read, S. (2010) The International Diffusion of Biotechnology: The Arrival of Developing Counties, A presentation to the International Schumpeter Society, Aalborg, June 2010.

Okimoto, D. (1989) Between MITI and the Market, Japanese Industrial Policy for High Technology, Stanford University Press, Stanford.

Okimoto, D., Sugano, T. and Weinstein, F.B. (Eds.) (1984) Competitive Edge, the Semiconductor Industry in the US and Japan, Stanford University Press, Stanford.

Perez, C. and Soete, L. (1988) 'Catching up in technology: entry barriers and windows of opportunity', in Dosi, G. et al (Eds.): Technical change and Economic Theory, pp.458/79, Pinter, London.

Prevezer, M. (2001) 'Ingredients in the early development of the US biotechnology industry', Small Business Economics, Vol. 17, Nos. 1-2, pp.17-29.

Reinert, E. (2007) How Rich Countries Got Rich and Why Poor Countries Stay Poor, Constable, London.

Thorsteinsdóttir, H. et al. (2010) 'South-South entrepreneurial collaboration in health biotech', Nature Biotechnology, Vol. 28, No. 5, pp.407-418.

Tijssen, R.J.W. (2009) 'Internationalization of pharmaceutical R\&D: how globalised are Europe's largest pharmaceutical companies?', Technology Analysis and Strategic Management, Vol. 21, No. 7, pp.859/79.

van Pottelsberghe, B. (2007) The Economic of the European Patent System, IP Policy for Innovation and Competition, Oxford University Press, Oxford.

Vernon, R. (1966) 'International investment and international trade in the product life cycle', QJE, Vol. 80, No. 2, pp.190-207.

Wells Jr., L.T. (1983) Third World Multinationals, MIT Press, Boston, MA.

World Bank (1993) The East Asian Miracle. Economic Growth and Public Policy, Oxford University Press, New York. 


\section{Notes}

1 By 2010, the population of the median country of the world is 4.5 million people. This is the size of Finland, Singapore or Uruguay.

2 EPO is an hormone that stimulates the production of blood red cells.

3 One exception is Nimotuzumab, a monoclonal antibody being developed at the Cuban Centre for Molecular Immunology, with the collaboration of Canada's YM Biosciences, and soon to be marketed by several companies in Argentina, Brazil, China, Colombia, Japan, and Mexico. See other cases that provide some caveat, without altering the general picture, to the argument of this paper (Thorsteinsdóttir et al., 2010). 